Arch. Tierz., Dummerstorf 47 (2004) 4, 337-349

Aus dem Institut für Tierzucht und Tierhaltung der Christian-Albrechts-Universität zu Kiel, Germany

JOACHIM KRIETER

\title{
Evaluation of Salmonella surveillance in pigs using a stochastic simulation model
}

\begin{abstract}
Pork is an important source of human Salmonellosis. Therefore efficient Salmonella surveillance programmes are recommended for minimising Salmonella entry into food production. With a stochastic simulation model, a Salmonella control programme (based on meat juice samples) was analysed depending on sample size (30 to 200 animals per finishing farm and year), prevalence in the population (8,13 and $24 \%$ ), farm size (400, 1500 and 3000 places per farm), threshold level classifying a farm as positive (20 and $40 \%$ ) and sensitivity of the test. The simulation model generates an integrated pig production chain with linkages between the stages farrowing, rearing, fattening and slaughter starting with the purchase of gilts. Salmonella may enter the system via purchase of animals, feedstuffs and other vectors. Crowding effects and pen-to-pen infection were also taken into account. Within each herd a dynamic pattern of Salmonella infection was simulated. The simulation covered a time interval of 24 months. Sensitivity, specificity and the predictive values were used for the evaluation of the different sampling strategies.

At the base situation (prevalence 8\%, 1500 places per finishing farm, 60 animals sampled per year and a threshold of $40 \%$ ) sensitivity was 65.9 and specificity $96.6 \%$. Increasing the sample size mainly improved the sensitivity (74.2 to $77.0 \%$ ). If the prevalence in the population is enhanced, more animals have to be sampled in order to realise the same detection rate. The effect of the farm size was negligible. The pattern of the Salmonella infection within a farm over 24 months demonstrated that a classification of farms supposes a handling time of 12 months.
\end{abstract}

Key Words: pig-microbiological disease, salmonella surveillance, simulation model, evaluation

\section{Zusammenfassung}

Titel der Arbeit: Analyse des Salmonella-Monitorings beim Schwein mit einem stochastischen Simulationsmodell

Schweinefleisch stellt eine bedeutende Infektionsquelle für die Salmonellose beim Menschen dar. Deshalb sind effiziente Kontrollstrategien notwendig, um den Eintrag von Salmonellen in die Lebensmittelkette zu minimieren. Mit einem stochastischen Simulationsmodell wurde ein Salmonella Kontrollprogramm (basierend auf Fleischsaftproben) in Abhängigkeit von der Stichprobengröße (30 bis 200 Schlachtschweine je Mastbetrieb und Jahr), der Prävalenz (8, 12 und 24\%), der Betriebsgröße (400, 1500 und 3000 Mastplätze je Jahr) analysiert. Zusätzlich wurden der Schwellenwert für die Kategorisierung der Bestände (20 und 40\%) und die Sensitivität des Testverfahrens variiert. Das Simulationsmodell generiert ein integriertes Produktionssystems beim Schwein mit den Stufen Ferkelerzeugung, Aufzucht, Mast und Schlachthof. Die Einschleppung der Salmonellen erfolgt über den Zukauf von Tieren, Futtermitteln und anderen Vektoren, Crowding-Effekte und Infektionen zwischen benachbarten Buchten wurden berücksichtigt. Innerhalb eines Betriebes wurde ein dynamischer Verlauf der Salmonella-Infektion abgebildet. Der Zeitraum der Untersuchungen erstreckte sich auf 24 Monate. Zur Bewertung der unterschiedlichen Kontrollstrategien wurden die Sensitivität und die Spezifität berechnet.

In der Basissituation (Prävalenz 8\%, 1500 Mastplätze je Betrieb), Stichprobengröße 60 Tiere je Jahr, Schwellenwert 40\%) erreichten die Sensitivität und Spezifität Werte von 65,9 und 96,6\%. Eine steigende Stichprobenzahl erhöhte in erster Linie die Sensitivität, höhere Prävalenzen in der Population führten zu einer Anhebung des erforderlichen Stichprobenumfangs bei einer gleichen Genauigkeit. Der Einfluss der Betriebsgröße war zu vernachlässigen. Der betriebsspezifische Verlauf Salmonella Infektion über eine Zeitperiode von 24 Monaten verdeutlicht, dass die Kategorisierung der Betriebe eine Vorlaufzeit von 12 Monaten beansprucht.

Schlüsselwörter: Zoonosen, Salmonella Kontrollprogramm, Simulation 


\section{Introduction}

Human salmonellosis has always been one of the most common illnesses transferred by foodstuffs. In 2001, 76,732 cases were registered in Germany (RKI, 2002; German population: 80 million people). With an estimated number of unknown cases of 80 to $90 \%$, the number of actual illnesses is between 400,000 and 800,000 . For the Netherlands it has been estimated that about 52,000 cases of human salmonellosis occur in the Dutch population of 15 million people each year (VAN PELT et al., 1999). TODD (1989) calculated the cost per patient in the USA due to food born diseases at 700 to 1,350 \$. Assuming German proportions the cost would account for 125 to 250 million $€$ each year.

The main source of infection for humans is the consumption of contaminated foodstuffs made from animals. Foodstuffs originating from pigs cause 15 to $25 \%$ (STEINBACH und KROELL, 1999; BERENDS et al., 1998; VAN PELT et al., 2000). The salmonella prevalence at the primary sector differed between individual animals and herds. In a study from ALTROCK et al. (2000) $7.3 \%$ of the serologically investigated fattening pigs were positive. PROTZ et al. (1997) found a seroprevalence of $7.7 \%$ at the fattening level. In Austria, KÖFER et al. (2000) reported a low seroprevalence of 2.4\%. NIELSEN and WEGENER (1997) presented a percentage of positive meat drip samples in Denmark from 4 to 7\%. According to VAN DER WOLF (2000), the population prevalence for finishers was $24 \%$ in the Netherlands. Evaluations concerning the herd Salmonella prevalence range up to 60 and $80 \%$ (BERENDS et al., 1996; STEINBACH and KROELL, 1999). The results of these studies are difficult to compare since sample material, extraction techniques, analysis procedure and the fixed limit values are different. One should also be aware that not every infected pig shows positive results and only samples are investigated.

The minimisation of Salmonella entry into the production chain is an important requirement in food safety and consumer protection and requires efficient Salmonella monitoring tools. NIELSEN et al. (2001) pointed out that due to the Danish Salmonella surveillance and control programme, which classify the finishers herds with a serological test (Salmonella antibodies in the meat juice), Salmonella in pork declined from 3.5\% in 1993 to $0.7 \%$ in the year 2000. In year 2001, classification was improved. Individual test cut-off was reduced from 40 to 20 OD\% and the sample size was adapted to the herd size (from 60 to 100 animals per farm and year). OSTERKORN et al. (2001) investigated Salmonella sampling for slaughter pigs using different spot-check plans. The model calculation demonstrated that first a sampling of 30 animals per farm and year is adequate. If the number of positive samples exceeds two animals, sample size should be increased to 60 animals per year. The present study investigates different control strategies based on meat drip losses with Monte Carlo methods within a vertically integrated pig production chain. Farm size, prevalence in the population, threshold level, sample size and the sensitivity of the test were varied with respect to the detection rate of the control programme.

\section{Material and Methods}

\section{General concept}

In general the simulation model includes an integrated pig production chain with vertical linkages between the four stages farrowing, rearing, fattening and slaughter of 
pigs. In the farrowing stage, feeder pigs were produced which are passed on to the fattening stage at a live weight of $28 \mathrm{~kg}$. Animals were slaugthered at a live weight of $115 \mathrm{~kg}$.

The model starts with the generation of sow performance. Based on a gestation of 115 days, lactation length (28 days) and seven days from weaning to first breeding, the production cycle was at least 150 days, on average the production cycle was prolonged due to reproduction failures. Litter size and piglet mortality was simulated over ten litters with nonlinear patterns for litter size born alive and piglet mortality (BRANDT, 1984). An average of 10.2 piglets were born alive and piglet mortality varied between 13.3 and 18.1. Culling percentage of sows differed between litters (12 to 30\%). Culled sows were replaced by gilts each month and were integrated into the herd with 180 days. The growth performance of feeder and fattening pigs were described using the Gompertz function (DOURMAD et al., 1992; KRIETER and KALM, 1989). Daily gain of feeder and finishing pigs was 420 and $720 \mathrm{~g}$. 14 days were needed to empty, clean and desinfect batches. Postwening mortality was $1 \%$, during fattening the mortality rate amounted to $3 \%$.

The simulation model includes possible crowding effects (e.g. stress, higher infection risk) between the different stages of the production chain. After weaning, three litters were housed in one large group within the farrowing farm at one time (respectively). Each breeding herd supplied two finishing farms which split the piglets into two batches after transport. At the end of the finishing period animals were transported to the slaughterhouse, the capacity of the truck was fixed at 40 pigs per floor (e.g. three or four batches). These groups of animal remained constant at the slaughter house.

As shown by van der Wolf (2000) the in-herd Salmonella prevalence fluctuates within a given time period. To make allowances for this variation, the duration of the simulation was extended to 24 months.

\section{Entry and spread of Salmonella in vertically integrated production chain}

The model considers several alternatives for the Salmonella entry in the production chain (see Figure 1, Table 1). The probability of an infection due to the risk factors varied between stages and depended on the prevalence in the population. The most important source of Salmonella introduction for all stages was the acquisition of infected animals from the preliminary stage. Latently infected animals which enter the herd unnoticed due to the lack of clinical symptoms can intermittently pass salmonella out via the faeces. The occurrence of Salmonella in feed is mostly a consequence of recontamination during production, transport or storage. The probability of an infection due to feed stuffs ranged from 0 to $10 \%$. Reported prevalence of Salmonella positive rodents were between 0 and $30 \%$ (ROLLE and MAYR, 1993). In the model it was assumed that rodents mainly initialise and maintain the contamination cycle at the farm. This risks were higher in breeding farms compared to finishing farms (due to e.g. all-in-all-out, cleaning and disinfections).

The transmission of Salmonella in the vertical production chain depends on the Salmonella status of the sow at the breeding farm. Suckling piglets can be infected by perinatal contamination and the faeces of the sow. The probability that infected sows excreted Salmonella with the faeces ranged between 0 and 95\% depending on the general Salmonella status of the farm. The risk for a piglet becoming infected by the contaminated faeces of the sow varied from 20 to $90 \%$. Each alteration of the stage 
caused an increase in prevalence due to crowding. Crowding was considered from lactation to weaning, weaning to finishing and finishing to slaughter (including transport). Two patterns of the spread of infection within units were taken into account. First, if a pen has a known number of animals infected $\left(\mathrm{n}_{\mathrm{i}}\right)$ after arrival the proportion of infected animals $\left(\mathrm{pu}_{\mathrm{i}}\right)$ was updated with

$$
\mathrm{pu}_{\mathrm{i}}=\mathrm{n}_{\mathrm{i}} / \mathrm{N}+\mathrm{c}\left[\mathrm{n}_{\mathrm{i}} / \mathrm{N}\left(1-\exp -\left(1-\mathrm{n}_{\mathrm{i}} / \mathrm{N}\right)\right)\right]
$$

$\begin{array}{llll}\text { Stage } & \text { Status } & \text { risk factor }\end{array}$

Breeding farm

Sow

piglet-lactation

Finishing pig

Slaughter-house

Piglet-weaning

Transport

$0 / 1$

0

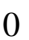

0

$$
\text { 0/1 }
$$$$
\text { - }
$$

-

1 Replacement Vectors ${ }^{1)}$

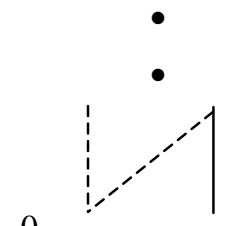<smiles>ICCI</smiles><smiles>C1CCCCC1</smiles>

\section{Crowding}

1
1
$1 / 0$

Pen to pen

Vectors ${ }^{1)}$

Dynamic $^{2)}$

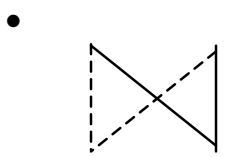

0

$0 / 1$

$0 / 1$

(1)<smiles>C1CC12CC2</smiles>

$0 / 1$<smiles>ICCCI</smiles>

0

1

$\begin{array}{cl} & \text { Purchase of animals } \\ & \text { Crowding } \\ 1 & \text { Pen to pen } \\ 1 & \text { Vectors }^{1)} \\ 1 / 0 & \text { Dynamic }^{2)} \\ & \text { Crowding } \\ & \text { Pen to pen } \\ 1 & \\ 1 & \end{array}$

Crowding
Piglets born alive

Mortality

Culling

Replacement

Litter/sow/year

Daily gain

Mortality

Daily gain

Mortality

Production cycle

Daily gain

Mortality

Production cycle

Sampling

\footnotetext{
${ }^{1)}$ feed, rodents, birds, dust implements

${ }^{2)}$ probability delivery negative animals which were tested postive at the previous stage
}

Fig. 1: Structure of the simulation model (Struktur des Simulationsmodells)

$\mathrm{N}$ is the total number of animals per pen and $\mathrm{c}$ is a weighting factor depending on the stage considered. Parameter c diminishes the probability of spreading the infection at the weaning stage (0.10) and increases the risk at the fattening level (0.50) and at 
transport and slaughter house (0.80). Over time the seroprevalence declines, therefore it is possible to deliver finishers seronegatives to the slaughterhouse which were positive as growers. The probabilities of supplying negatives pigs which were positive at weaning or at starting the finishing period were 10 and $40 \%$.

Secondly, infections will spread from adjacent pen to adjacent pen within a barn due to faeces and other vectors (e.g. boots, overalls and other implements). The probability of pen-to-pen transmission was set to $30 \%$ at weaning, $60 \%$ at finishing and $80 \%$ at transport. The Salmonella transmission from barn to barn was neglected in the model.

Table 1

Description of the model inputs (Inputparameter des Simulationsmodells)

\begin{tabular}{|c|c|c|c|}
\hline Description of variables & mean & $\min$ & $\max$ \\
\hline \multicolumn{4}{|l|}{$\overline{\text { Production }}$} \\
\hline \multicolumn{4}{|l|}{ Breeding } \\
\hline \multicolumn{4}{|l|}{ Sows } \\
\hline Piglets number born alive per litter ${ }^{1)}$, piglet & 10.2 & 8.6 & 11.5 \\
\hline Mortality (piglets), \% & 15.3 & 13.3 & 18.1 \\
\hline Lactation period, days & 28 & & \\
\hline Weaning-to-oestrus interval, days & 7 & & \\
\hline Litters per sow and year, $\mathrm{n}$ & 2.29 & & \\
\hline Replacement rate, \% & 40 & & \\
\hline \multicolumn{4}{|l|}{ Weaning (7 to $28 \mathrm{~kg}$ live weight) } \\
\hline Daily gain, g & 420 & & \\
\hline Mortality, \% & 1 & & \\
\hline Production cycle & 6.1 & & \\
\hline \multicolumn{4}{|l|}{ Finishing ( $>28$ to $115 \mathrm{~kg}$ live weight) } \\
\hline Daily gain, g & 720 & & \\
\hline Mortality, \% & 3 & & \\
\hline Production cycle & 2.7 & & \\
\hline \multicolumn{4}{|l|}{ Salmonella introduction } \\
\hline \multicolumn{4}{|l|}{ Breeding farm } \\
\hline \multicolumn{4}{|l|}{ Sows } \\
\hline Prevalence replacement gilts, \% & - 2) & 0 & 90 \\
\hline \multicolumn{4}{|l|}{ Probability of an infection due to, \% } \\
\hline Feed, water & - 2) & 0 & 10 \\
\hline Rodents & $-2)$ & 0 & 5 \\
\hline Others & $-2)$ & 0 & 10 \\
\hline \multicolumn{4}{|l|}{ Lactation and weaning (piglets) } \\
\hline \multicolumn{4}{|l|}{ Probability of an infection due to, \% } \\
\hline Feed, water & $-2)$ & 0 & 2 \\
\hline Rodents & $-2)$ & 0 & 1 \\
\hline Others & $-2)$ & 0 & 2 \\
\hline \multicolumn{4}{|l|}{ Finishing } \\
\hline \multicolumn{4}{|l|}{ Probability of an infection due to, \% } \\
\hline Feed, water & $-2)$ & 0 & 10 \\
\hline Rodents & $-2)$ & 0 & 2.5 \\
\hline Others & - 2) & 0 & 5 \\
\hline \multicolumn{4}{|l|}{ Salmonella transmission } \\
\hline \multicolumn{4}{|l|}{ Breeding farm } \\
\hline \multicolumn{4}{|l|}{ Sows, piglets - suckling period } \\
\hline Probability - excretion of Sal. via faeces by infected sows & $-2)$ & 10 & 95 \\
\hline Probability - infection of piglets by sows infected & $-2)$ & 20 & 90 \\
\hline \multicolumn{4}{|l|}{ Weaning } \\
\hline Crowding, no. litters per pen & 3 & & \\
\hline Crowding factor, $\mathrm{c}^{3)}$ & 0.10 & & \\
\hline Probability for the infection from pen to pen, \% & 30 & & \\
\hline $\begin{array}{l}\text { Probability that animals tested negatively at } 28 \mathrm{~kg} \text { which } \\
\text { were tested positive during lactation }\end{array}$ & 10 & & \\
\hline
\end{tabular}


Table 1 (cont.)

\begin{tabular}{|c|c|c|c|}
\hline Description of variables & mean & $\min$ & $\max$ \\
\hline Finishing & \multicolumn{3}{|c|}{ Salmonella transmission, cont. } \\
\hline Crowding, no. pen per pen (weaning) & 2 & & \\
\hline Crowding factor, $\mathrm{c}^{3)}$ & 0.50 & & \\
\hline Probability for the infection from pen to pen, \% & 60 & & \\
\hline $\begin{array}{l}\text { Probability that animals tested negatively at } 115 \mathrm{~kg} \text { which } \\
\text { were tested positive during weaning }\end{array}$ & 40 & & \\
\hline \multicolumn{4}{|l|}{ Transport/slaughter house } \\
\hline Crowding, 3 or 4 pen, pigs per floor & 40 & & \\
\hline Crowding factor, $\mathrm{c}^{3)}$ & 0.80 & & \\
\hline Probability for the infection within floor, \% & 80 & & \\
\hline
\end{tabular}

\section{Sampling scheme}

Finishing herds were tested for Salmonella antibodies (NIELSEN et al., 2001) at the slaughterhouse using a defined random sample size. Samples were collected from six or twelve different deliveries per year to the slaughterhouse in order to guarantee a random selection over time and over different compartments within the herd. The sampling procedure was independent from the herd size. Sampling results were used to estimate the seroprevalence within the herd at a given time $t$ ( $\mathrm{p}_{\text {wh.t }}$ ). If $\mathrm{p}_{\text {wh.t }}$ (summarized over the last three deliveries by moving average) exceeded a fixed threshold level (20 or $40 \%$ ), the herd was treated as Salmonella positive.

The sampling procedure was evaluated using the classification into infected (true positives, TP) and non-infected (true negatives, TN) herds with the classification accuracy defined as $(\mathrm{TP}+\mathrm{TN}) / \mathrm{N}$. The degree of misclassification was expressed by false positive (FP) and false negative (FN) events. From these figures sensitivity (SE) and specificity (SP) were calculated within farms and over the specific time period. The sensitivity is the probability that a truly infected herd will be classified as infected with the sampling procedure $\left(\mathrm{SE}=\mathrm{TP} *[\mathrm{TP}+\mathrm{FN}]^{-1}\right)$. The specificity is the probability that a truly non-infected herd is classified as non-infected using the test $\left(\mathrm{SP}=\mathrm{TN} *[\mathrm{TN}+\mathrm{FP}]^{-1}\right)$. Furthermore the predicitive values were investigated. The number of herds tested positive in relation to TP and FP is called the positive predicitve value $\left(\mathrm{PV}^{+}=\mathrm{TP} *[\mathrm{TP}+\mathrm{FP}]^{-1}\right)$. The negative predictive value $\left(\mathrm{PV}^{-}\right)$ corresponds to the proportion of herds tested negative while they are truly non-infected $\left(\mathrm{PV}^{-}=\mathrm{TN} *[\mathrm{TN}+\mathrm{FN}]^{-1}\right)$. The predictive values depend on the Salmonella prevalence in the population. If the Salmonella prevalence is low, TPs decrease and FPs increase resulting in low $\mathrm{PV}^{+}$(assuming constant $\mathrm{SE}$ and $\mathrm{SP}$ ).

\section{Simulation scenarios}

SE and SP depend on several criteria including the prevalence of infected animals within farms, herd size, the number of animals tested, the accuracy of the individual animal test and the threshold of positive individual animal tests chosen to declare a herd as positive (Table 2).

The prevalence in the total population was determined by the number of herds truly infected and the within herd prevalence. Based on a review of published literature, the in-herd prevalence was set between 0 and $70 \%$. Five herd classes with different 
prevalence levels were established to give an overall prevalence at the population level from 8,13 or $24 \%$.

Table 2

Parameters of alternate simulation scenarios (Alternative Simulationsszenarien)

\begin{tabular}{ll}
\hline Parameter & \multicolumn{1}{c}{ Value $^{1)}$} \\
\hline Herd size & $50,210,420$ \\
Farrowing, sows & $400,1500,3000$ \\
Fattening, places & \\
Sampling size (meat juice) & $30,60,100,200$ \\
Carcass per farm and year, $n$ & $8,13,24$ \\
Salmonella prevalence at the population level, \% & 20,40 \\
Threshold level > positive, \% ${ }^{2)}$ & $0,20,40,60$ \\
Test accuracy, \% & \\
${ }^{1)}$ italics: base situation & \\
${ }^{2)}$ proportion of positive individual-test to declare a farm as positive & \\
${ }^{3)}$ proportion of false-negatives (meat juice, antibodies)
\end{tabular}

In the base situation herd size at the farrowing stage was set to 210 productive sows, at the fattening level 1500 places per farm were assumed implying 2.7 production cycles realised per year (Table 2). Herd size was varied between 50 and 420 sows representing the herd size distribution in the nothern and eastern parts of Germany. The number of animals tested ranged from 30 to 200 animals per farm and year at the fattening level. The base sample size was fixed to 60 animals according to the recommended regulations in Germany. Screening of sows at the farrowing level was omitted in the present study.

Farms were classified as Salmonella positive if the proportion of positive individual tests (weighted from the last recent three periods) exceeded 20 or $40 \%$ (threshold level). STEINBACH and KROELL (1999) demonstrate that the SE of the serological test is low if antibody extinction and Salmonella in faeces and/or lymph nodes are compared. Therefore the proportion of false negatives was varied from 0 (base) to $60 \%$.

In total 100 farms were simulated with 1000 replicates.

\section{Results}

\section{Base situation}

The base situation is described with a herd size of 210 productive sows and 1500 places per finishing farm. The Salmonella prevalence in the population was set to $8 \%$, 60 animals per farm were serologically tested. At a threshold of $40 \%$ the probability that a truly infected herd will be classified as positive (sensitivity) was $65.9 \%$. The specificity, the probability that a truly non-infected herd is classified as negative, was much higher (96.9\%). These results were expected since more than $80 \%$ of the farms simulated showed a low Salmonella prevalence with a relative small number of false positives. Therefore the proportion of animals tested negatively was $94.8 \%$, conversely the positive predictive value only accounted for $31.7 \%$.

In Figure 2 the pattern of the true and estimated population prevalence is presented over a time period of 24 months. The fluctuation of the true values ranged from 7.4 to $9.0 \%$ due to random drift. With increasing prevalences (not presented) the absolute deviations between subsequent observations increase because a greater proportion of herds exceeded a prevalence of zero. The fluctuation margin of the estimated prevalence amounts to $4.6 \%$ (from 6.2 to 10.8 ) with a maximum bias (difference 
between true and estimated value) of $2.1 \%$. As expected the standard deviation of the estimated values was $\sigma=1.02$ (compared to $\sigma=0.31$ of the true values) demonstrating the higher fluctuation of the estimated values.

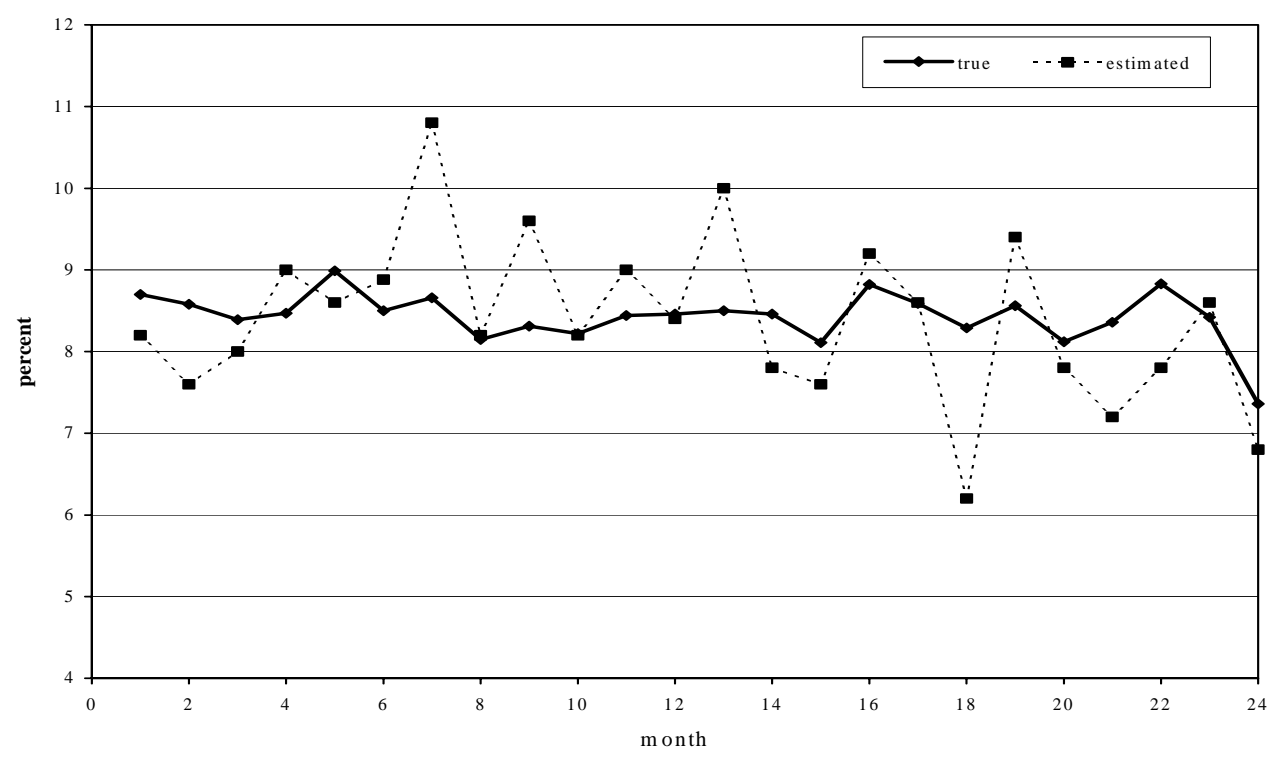

Fig. 2: Pattern of the true and estimated population prevalence (210 sows, 4080 growers, sample size: 60 animals per farm and year, true prevalence: 8\%) (Verlauf der wahren und geschätzten Prävalenz in der Population)

\section{Sample size}

The accuracy of the screening method was mainly determined by the sample size (Table 3). Increasing sample size (30 to 200 animals per finishing farm and year) improved the sensitivity from 76.5 to $86.3 \%$ (threshold $20 \%$ ). The highest gain in SE (5.5\%) was observed between sample sizes of 30 and 60 animals. Comparable results were found for the specificity with explicitly higher absolute values from 88.0 to 97.6 $\%$.

$\mathrm{PV}^{+}$drastically increased from 16.4 to $72.9 \%$ due to the reduction of false positives results which was also indicated by the enhanced specificity. The improvement of the negative predictive value ( $\mathrm{PV}^{-}$) with an increased sample size was much smaller (from 87.2 to $93.2 \%)$.

\section{Table 3}

Sensitivity (SE, \%), specificity (SP, \%), positive predicitive value $\left(\mathrm{PV}^{+}, \%\right)$ and negative prediticive value $\left(\mathrm{PV}^{-}\right.$, \%) depending on sample size (animals per finishing farm and year) and threshold (Sensitivität, Spezifität sowie Vorhersagegenauigkeit der positiven und negativen Ereignisse in Abhängigkeit von dem Stichprobenumfang und dem Schwellenwert)

\begin{tabular}{cccccc}
\hline Threshold & Sample size & SE & SP & PV $^{+}$ & PV $^{-}$ \\
\hline \multirow{3}{*}{20} & 30 & $76.5(1.65)^{1)}$ & $88.0(0.46)$ & $16.4(1.22)$ & $87.2(1.04)$ \\
& 60 & $82.0(1.65)$ & $95.2(0.46)$ & $39.4(2.46)$ & $88.7(0.99)$ \\
& 100 & $83.4(1.77)$ & $96.3(0.46)$ & $60.1(3.00)$ & $91.4(0.88)$ \\
& 200 & $86.3(1.71)$ & $97.6(0.36)$ & $72.9(2.96)$ & $93.2(0.78)$ \\
\hline \multirow{2}{*}{40} & 30 & $61.3(3.30)$ & $96.1(0.37)$ & $23.3(2.71)$ & $94.8(0.69)$ \\
& 60 & $65.9(2.90)$ & $96.9(0.35)$ & $31.7(3.46)$ & $94.8(0.69)$ \\
& 100 & $74.2(2.41)$ & $97.7(0.30)$ & $39.5(3.95)$ & $95.0(0.68)$ \\
& 200 & $77.0(2.66)$ & $98.3(0.25)$ & $46.2(4.32)$ & $95.2(0.67)$ \\
\hline
\end{tabular}

1) mean value (standard error)

If the threshold level was set to $40 \%$, the highest gain in SE was found between 60 and 100 animals per farm and year, the effect on the specificity was negligible. PV 
was low with 39.5 and $46.2 \%$ (60 and 100 animals per year). Contrary PV always reached high values independently from sample size because true negative observations outweighed the false negatives.

Table 4

Sensitivity (SE, \%), specificity (SP, \%), positive predicitive value $\left(\mathrm{PV}^{+}, \%\right)$ and negative prediticive value (PV , $\%$ ) depending on farm size and threshold (Sensitivität, Spezifität sowie Vorhersagegenauigkeit der positiven und negativen Ereignisse in Abhängigkeit von der Betriebsgröße und dem Schwellenwert)

\begin{tabular}{cccccc}
\hline Threshold & $\begin{array}{c}\text { Farm size } \\
\text { Farrowing/fattening }\end{array}$ & SE & SP & $\mathrm{PV}^{+}$ & $\mathrm{PV}^{-}$ \\
\hline \multirow{3}{*}{20} & $50 / 400$ & $79.4(1.73)$ & $95.2(0.37)$ & $34.9(2.15)$ & $90.3(0.88)$ \\
& $210 / 1500$ & $82.0(1.65)$ & $95.2(0.46)$ & $39.4(2.46)$ & $88.7(0.99)$ \\
& $420 / 3000$ & $82.9(1.52)$ & $95.9(0.40)$ & $39.2(2.49)$ & $88.5(1.02)$ \\
\hline \multirow{3}{*}{40} & $50 / 400$ & $63.8(2.57)$ & $95.4(0.47)$ & $35.8(3.06)$ & $94.9(0.62)$ \\
& $210 / 1500$ & $65.9(2.90)$ & $96.9(0.35)$ & $31.7(3.46)$ & $94.8(0.69)$ \\
& $420 / 3000$ & $65.7(3.14)$ & $96.7(0.36)$ & $32.3(3.51)$ & $94.9(0.69)$ \\
\hline
\end{tabular}

${ }^{1)}$ number of productive sows / number of places per fattening farm

\section{Herd size}

The number of productive sows per breeding farm ranged from 50 to 420, at the fattening level 1020, 4080 and 8160 pigs were slaughtered per farm and year, assuming 2.7 production cycles per place, fattening farms had approximately 400 to 3000 places. As shown in Table 4 the impact of different herd sizes on the test criteria was only limited. With increasing herd size $\mathrm{SE}$ and $\mathrm{PV}^{+}$were slightly improved (threshold $20 \%$ ), but the results of the different scenarios overlapped due to the high standard errors. SP and $\mathrm{PV}^{-}$were unaffected by different numbers of animals per farm. Increasing the threshold to $40 \%$ yielded SE between 63.8 and $65.7 \%$, the range of $\mathrm{PV}^{+}$amounted to 35.8 and $32.3 \%$. According to the results with a threshold of $20 \%$ the effect of different herd sizes on the efficiency of the sampling procedure was small.

Table 5

Sensitivity (SE, \%), specificity (SP, \%), positive predicitive value ( $\left.\mathrm{PV}^{+}, \%\right)$ and negative prediticive value ( $\mathrm{PV}^{-}$, $\%$ ) depending on the prevalence in the population and threshold (Sensitivität, Spezifität sowie Vorhersagegenauigkeit der positiven und negativen Ereignisse in Abhängigkeit von der Prävalenz und dem Schwellenwert)

\begin{tabular}{cccccc}
\hline Threshold & Prevalence & SE & SP & PV $^{+}$ & PV $^{-}$ \\
\hline \multirow{2}{*}{20} & 8 & $82.0(1.65)$ & $95.2(0.46)$ & $39.4(2.46)$ & $88.7(0.99)$ \\
& 13 & $82.1(1.14)$ & $90.9(0.68)$ & $55.1(2.07)$ & $77.4(1.33)$ \\
& 24 & $82.4(0.78)$ & $76.2(1.20)$ & $70.3(1.51)$ & $49.7(1.64)$ \\
\hline \multirow{2}{*}{40} & 8 & $65.9(2.90)$ & $96.9(0.35)$ & $31.7(3.46)$ & $94.8(0.69)$ \\
& 13 & $66.6(2.12)$ & $93.1(0.52)$ & $32.3(2.45)$ & $89.5(0.94)$ \\
& 24 & $68.1(1.35)$ & $85.1(0.68)$ & $32.6(1.74)$ & $79.6(1.25)$ \\
\hline
\end{tabular}

\section{Prevalence in the population}

The prevalence in the population was fixed with 8,13 and $24 \%$ in order to ensure a realistic figure for the simulation. In Table 5 the results concerning the alternate population status are presented for the medium herd size (210 sows, 4080 growers) and a sample size of 60 animals per year. If the prevalence rose, SE was unchanged because the ratio TP:FN remained constant even though the absolute number of TP and FN changed. $\mathrm{PV}^{+}$increased from $39.4 \%$ at $8 \%$ to $70.3 \%$ at $24 \%$, since the shift in the population level caused a stronger increase in the total number of infected animals compared to the number of false positive results. Conversely $\mathrm{PV}^{-}$declined from $88.7 \%$ ( $8 \%$ prevalence) to $49.7 \%$ ( $24 \%$ prevalence) because the number of FN 
increased disproportionately. The overall classification accuracy deteriorated by 11.6 \% (threshold $20 \%$ ) and $12.7 \%$ (threshold $40 \%$ ) if the prevalence in the population increased from 8 to $24 \%$. Fixing the threshold to $40 \%$ led to similar results, but the differences between the prevalence levels were much smaller. $\mathrm{PV}^{-}$was only reduced by $15.2 \%$ (threshold $20 \%: 39.0 \%$ ) and the improvement of $\mathrm{PV}^{+}$was restricted within the error margin (threshold $20 \%$ : $30.9 \%$ ).

The minor differences between the threshold levels are determined by the distinction of the threshold and the prevalence. If the prevalence and the threshold level showed nearly the same values, $\mathrm{PV}^{+}$improved and $\mathrm{PV}^{-}$declined compared to a situation with a large distance between the threshold and the prevalence. With an increasing distance between the prevalence and the threshold (assuming threshold > prevalence) the prediction of the relatively small number of positive results is even more difficult, the reverse could observed for the number of negative results.

\section{Table 6}

Percentage alteration of true positives (TP), true negatives (TN), false positives (FP) and false negatives (FN) with an increased proportion of false negatives test results (base situation without false negatives - meat juice, antibodies - was set to 100) (Prozentuale Veränderung der wahr bzw. falsch positiven und negativen Ergebnisse bei einem steigenden Anteil falsch negativer Testergebnisse)

\begin{tabular}{ccccc}
\hline \% False negatives & TP & TN & FP & FN \\
\hline 20 & 64.9 & 103.1 & 53.4 & 178.3 \\
40 & 29.2 & 105.3 & 21.6 & 254.0 \\
60 & 9.1 & 106.1 & 6.9 & 302.9 \\
\hline
\end{tabular}

Accuracy of the test

If the proportion of false negative test results (meat juice, antibodies) increased, the number of truly infected animals detected with the sampling was drastically diminished (Table 6). At a false negative rate of $20 \%$ the relative TP (related to the base situation) amounted to $64.9 \%$ and declined to $9.1 \%$ if the false negative rate was $60 \%$. As expected FP was also reduced to 53.4 and $6.9 \%$ (20 and $60 \%$ false negative results). The relative number of TN was only slightly increased (6.1\%) with a lower test accuracy due to the generally high absolute number of TN for the given scenarios (compared to relative small number of FP cases). In contrast, table 6 shows a marked increase in the FN accompanied by a low SE. SE ranged from 39.1 to $5.2 \%$ (20 and $60 \%$ false negative results). On the other hand, specificity was improved because TN increased and FP decreased.

\section{Individual farm pattern of the true and estimated prevalence}

The pattern of the true and estimated pervalence (monthly basis) for an individual medium sized farm with Salmonella problems are presented in Figure 3 over a time period of 24 months.

The true values ranged between 39.2 and $50.7 \%$ with a mean value of approximately $45 \%$. The fluctuations were due to different infection levels of barn and pens depending on the status of the individual animals at the different stages. If sampling is used to estimate the prevalence of the farm, the amplitude markedly increased. At a sample size of 60 animals per year, minimum and maximum values amounted to 16.1 and $64.4 \%$. If 100 animals were tested, the differences were slightly reduced to 25.7 and $67.6 \%$. Therefore the bias between the true and estimated values was large using monthly updated prevalences. From these results it is obvious that a reliable classification of the farms requires a preliminary investigation of approximately 12 months. 


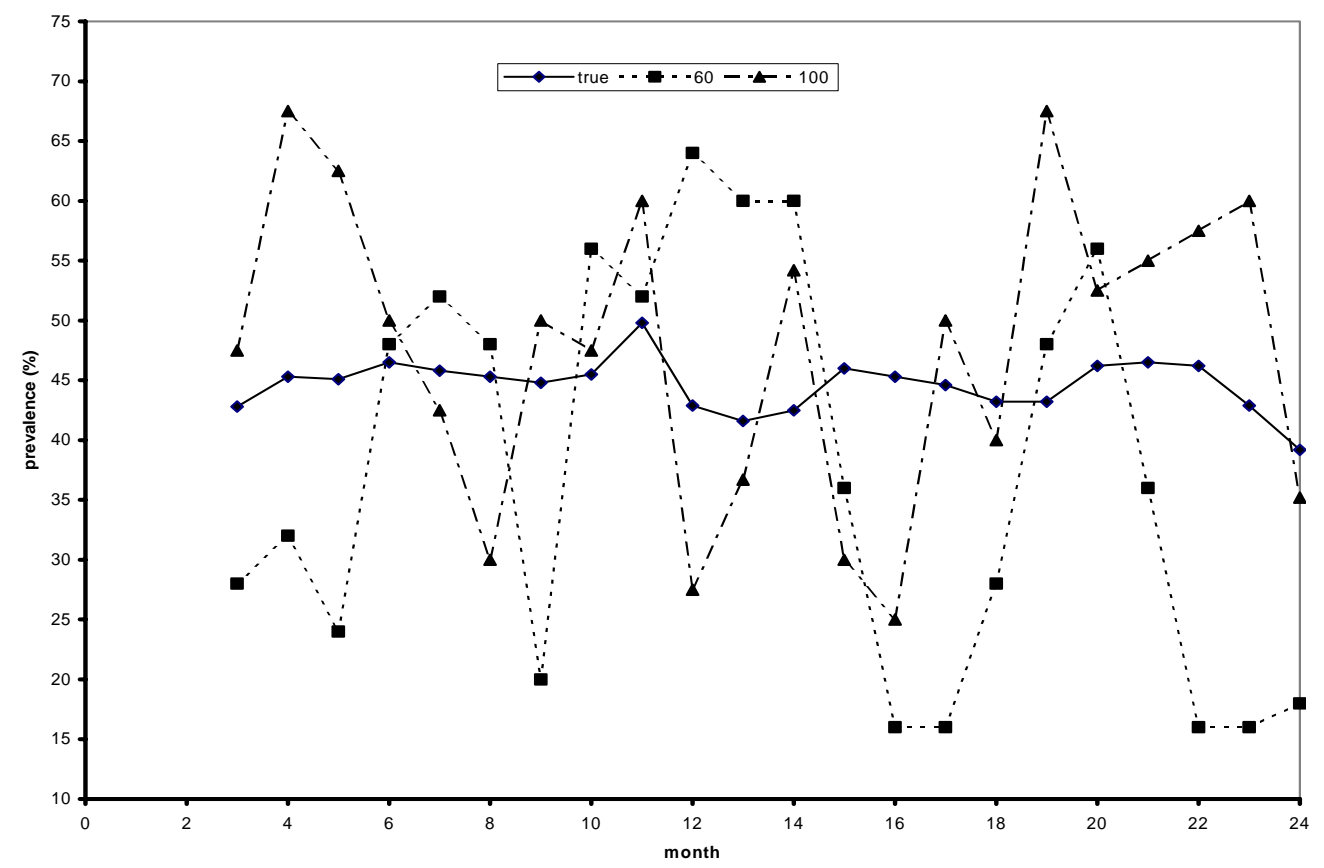

Fig. 3: Pattern of the true and estimated prevalence based on monthly sampling (sample size: 60 and 100 animals per farm and year) (Verlauf der wahren und geschätzten Prävalenz auf der Basis der monatlichen Stichprobenziehung

\section{Discussion}

The simulation model generates an integrated pig production chain starting with the purchase of sows at the breeding farm and closing with the transport and slaughter of the finishing pigs. At each stage Salmonella may enter the production chain by different vectors (e.g. latently infected animals, feed), the transmission is affected by the status of the sow, transport, crowding effects and pen-to-pen infections. Assumptions about the entry and spread of Salmonella were derived from the literature and were varied within biological limits. The aim of the present paper focused on the Salmonella surveillance depending on sample size, farm size, prevalence in the population and different threshold values classifying a herd as positive which not implicitly supposes a detailed description of the Salmonella transmission in the pig production chain (another paper deals with Salmonella control strategies, which need detailed information at each stage of the production). But in general, the simulation model provides a realistic figure of the Salmonella transmission in the production chain, which is also important for Salmonella monitoring systems if the Salmonella fluctuation within a farm over barns and time periods is to be considered.

In the German regulation, a sample size of 60 animals per finishing farm and year is required. The Danish surveillance system prescribes a sample size depending on the herd size (60 to 100 animals per year; NIELSEN et al., 2001). In the present study sample size varied between 30 and 200 animals per year. At a prevalence of $8 \%$ in the population, the classification accuracy increased from $87.8 \%$ (30 animals) to $97.4 \%$ (200 animals) at a threshold of $20 \%$; using a threshold of $40 \%$ the improvement was much smaller (94.9 to $97.5 \%$ ). The increment in the classification accuracy was mainly determined by the greater number of true positive results, which was also observed for the sensitivity ranging from 76.5 to $86.3 \%$ (at a threshold of $20 \%$ ). If the 
prevalence increased (24\%), the classification accuracy was at a lower level, $77.5 \%$ at a sample size of 30 animals and $90.2 \%$ if 200 animals per year were sampled. PV increased compared to a prevalence of $8 \%$ and $\mathrm{PV}^{-}$decreased since $\mathrm{PV}^{+}$and $\mathrm{PV}^{-}$are functions of the prevalence.

As mentioned above, in the Danish surveillance programme the sample size is graded depending on the herd size (NIELSEN et al., 2001). Small herds (annual kill $\leq 2000$ finishers) should be sampled with 60 animals per year, medium-sized farms (annual kill 2001-5000) with 75 and large herds (annual kill > 5000) with 100 animals per year (NIELSEN et al., 2001). OSTERKORN et al. (2001) pointed out that the required sample size slightly increased with larger finisher farms. The authors concluded that independently of the scale of the farm a sample size of 30 animals per year is sufficient given a threshold of $40 \%$ and a prevalence less than $10 \%$. The present study shows no definite relationship between farm size and detection rate. Detection rates were partly superposed by the fluctuation of the estimated prevalence over the time period of 24 months. These fluctuations were higher for smaller sized farms, which explains the slightly higher detection rate of farms with more animals. If samples were taken bimonthly, detection rates were more or less equal for the different farm sizes.

The prevalence in the population linked with the threshold level had a great impact on the identification of positive or negative results. If the prevalence increased, $\mathrm{PV}^{+}$was improved due to the stronger increase in the total number of infected animals compared to the number of false positives. $\mathrm{PV}^{-}$was reduced due to the stronger increase of FN. With increased prevalence in the population the total classification accuracy declined. At a threshold level of $20 \%$ and a prevalence of $8 \%$ the classification accuracy was $94.8 \%$; if the rate of infection increased (24\%), the accuracy amounted to $83.2 \%$. With increasing Salmonella prevalence in the population, sample size has to enhance to ensure the same detection rates. Similar results were also found by OSTERKORN et al. (2001).

STEINBACH and KROELL (1999) refer to the low sensitivity of the meat juice ELISA. If the number of false negatives increased, the probability that a truly infected farm is classified as infected was drastically diminished. Against this background and taking into account the prevalence and threshold level, a sample size of 30 animals per year proposed by OSTERKORN et al. (2001) is to small, especially if the prevalence in the population is increased. A lower limit of 60 and an upper limit of 100 animals per year seems more appropriate to optimise the probabilities that a truly non-infected farm is identified as non-infected and that a truly infected herd is classified as infected. These limits also improve food safety with regard to the consumer and also reduced the number of false positive results to a certain extent. In total, a higher number of false positive cases would cause an increase in production costs (e.g. consulting service, veterinarian) more than a larger sample size of 20 or 30 samples per farm.

\section{References}

ALTROCK, A.; SCHÜTTE, A.; HILDEBRANDT, G.:

Untersuchungsergebnisse aus Deutschland zu dem EU-Projekt "Salmonella in Pork (Salinpork)" - 1. Mitteilung: Untersuchungen in den Beständen. Berl. Münch. Tierärztl. Wschr. 113 (2000), 191-201

BERENDS, B.R.; URLINGS, H.A.P.; SNIJDERS, J.M.A.; VAN KNAPEN, F.: Identification and quantification of risk factors in animal management and transport regarding Salmonella spp. In pigs. Intern. J. Food Micobiol. 30 (1996), 37-53

BERENDS, B.R.; VAN KNAPEN, F.; MOSSEL, D.A.; BURT, S.A.; SNIDERS, J.M.A.: 
Impact on human health of Salmonella spp. on pork in The Netherlands and the anticipated effects of some currently proposed control strategies. Intern. J. Food. Microbiol., 44 (1998), 219-229

BRANDT, H.:

Konstruktion optimaler Selektionskriterien für die Sauenvermehrungsbetriebe mit eigener Bestandsremontierung. Institut für Tierzucht und Haustiergenetik der Universität Göttingen, Germany, Doctoral Thesis, 1984

DOURMAD, J.Y.; GUILLOU, D.; NOBLET, J.:

Develpoment of a calculation model for predicting the amount of $\mathrm{N}$ excreted by the pig: effect of feeding, physiological stage and performance. Live. Prod. Sci. 31 (1992), 95-107

KÖFER, J.; PLESS, P.; FUCHS., K.; THIEL, W.:

Aufbau eines Salmonella-Überwachungsprogrammes für die steierische Schweinefleischerzeugung. Wien. Tierärztl. Monatschr. 87 (2000), 14-20

KRIETER, J.; KALM, E.:

Growth, feed intake and mature size in Large White and Pietrain pigs. J. Anim. Breed. Genet. 106 (1989), 300-311

NIELSEN, B.; WEGENER, H.C.:

Public health and pork products: regional perspectives of Denmark. Rev. Sci. Tech., 16 (1997), 513-524

NIELSEN, B.; ALBAN, L.; HELLE, S.; SORENSEN, L.L.; MOGELMOSE, V.; BAGGER, J.; DAHL, J.;

BAGGESEN, D.L.:

A new Salmonella surveillance and control programme in Danish pig herds and slaughterhouses. Proc. 4th International Symposium on the Epidemiology and control of Salmonella and other food borne pathogens in pork, Leipzig, Germany, 14-21, 2001

OSTERKORN, K.; CZERNEY, C.P.; WITTKOWSKI, G.; HUBER, M.:

Stichprobenplanung für die Etablierung eines serologischen Salmonellen-Monitoringsprogramms bei Mastschweinen mittels Fleischsaft-ELISA. Berl. Münch. Tierärztl. Wschr. 114 (2001), 30-34

PROTZ, D.; KÄSBOHRER, A.M.; CONRATHS, K.; GEUE, L.:

Abschlußbericht zum "Salmonellen-Monitoring bei Schlachtschweinen aus deutscher Herkunft”. BMG and BML, 1997

RKI:

Epidemiologisches Bulletin, 18. Januar 2002, Heft 3; Robert Koch Institut, Berlin

ROLLE, M.; MAYR, A.:

Medizinische Mikrobiologie, Infektions- und Seuchenlehre für Tierärzte, Biologen, Agrarwissenschaftler und Interessierte aus benachbarten Fachgebieten. Lehrbuch für Praxis und Schulen. 6. Auflage, 1993, Verlag Enke, Stuttgart

STEINBACH, G.; KROELL, U.:

Salmonellainfektionen in Schweinebeständen - $\mathrm{Zu}$ ihrer Epidemiologie und Bedeutung für TODD, E.: Erkrankungen des Menschen. Dtsch. Tierärztl. Wschr. 106 (1999), 282-288

Preliminary estimates of costs of foodborne disease in the United States. J. Food. Protect. 52 (1989), $595-601$

VAN DER WOLF, P.J.:

Salmonella in the pork production chain: feasibility of Salmonella-free pig production. Department of Pig Health of the Animal Health Service, Utrecht, The Netherlands, PhD Thesis, 2000

VAN PELT, W.; VAN DE GIESSEN, A.W.; VAN LEEUWEN, W.J.; WANNET, W.; HENKEN, A.M.; EVERS, E.G.; DE WIT, M.A.S.; VAN DUYNHOVEN, Y.T.P.:

Oosrprong, omvang en kosten van humane salmonellose. Deel 1. Oorsprong van humane salmonellose met betrekking tot varken, rund, kip, ei en overige bronnen. Infectieziekten Bulletin, 10 (1999), 240-243

VAN PELT, W.; VAN DE GIESSEN, A.W.; VAN LEEUWEN, W.J.; WANNET, W.; HENKEN, A.M.; EVERS, E.G.; DE WIT, M.A.S.; VAN DUYNHOVEN, Y.T.P.:

Oosrprong, omvang en kosten van humane salmonellose. Deel 2. Schatting van de omvang van humane salmonellose in Nederland en daarmee gepaard gaande economische kosten. Infectieziekten Bulletin, 11 (2000), 4-8

Received: 2004-02-06

Accepted: 2004-06-24

Author's address

Prof. Dr. habil. JOACHIM KRIETER

Institut für Tierzucht und Tierhaltung der Christian-Albrechts-Universität zu Kiel

Olshausenstraße 40

D-24098 Kiel / Germany 